\title{
Congenital nephrogenic diabetes insipidus accompanied with central nephrogenic diabetes secondary to pituitary surgery -a case report
}

Wei Zhang ${ }^{1,2+}$, Yimin Shen ${ }^{3 \dagger}$, Yuezhong Ren ${ }^{4}$, Yvbo Xin ${ }^{1,2}$ and Lijun Wang ${ }^{1,2^{*}}$

\begin{abstract}
Background: Diabetes insipidus (DI) can be a common cause of polydipsia and polyuria. Here, we present a case of congenital nephrogenic diabetes insipidus (CNDI) accompanied with central diabetes insipidus (CDI) secondary to pituitary surgery.

Case presentation: A 24-year-old Chinese woman came to our hospital with the complaints of polydipsia and polyuria for 6 months. Six months ago, she was detected with pituitary apoplexy, and thereby getting pituitary surgery. However, the water deprivation test demonstrated no significant changes in urine volume and urine gravity in response to fluid depression or AVP administration. In addition, the genetic results confirmed a heterozygous mutation in arginine vasopressin receptor type 2 (AVPR2) genes.

Conclusions: She was considered with CNDI as well as acquired CDI secondary to pituitary surgery. She was given with hydrochlorothiazide (HCTZ) $25 \mathrm{mg}$ twice a day as well as desmopressin (DDAVP, Minirin) $0.1 \mathrm{mg}$ three times a day. There is no recurrence of polyuria or polydipsia observed for more than 6 months. It can be hard to consider AVPR2 mutation in female carriers, especially in those with subtle clinical presentation. Hence, direct detection of DNA sequencing with AVPR2 is a convenient and accurate method in CNDI diagnosis.
\end{abstract}

Keywords: Polyuria, Nephrogenic diabetes insipidus, Central nephrogenic diabetes, AVPR2 mutation

\section{Background}

Diabetes insipidus (DI) can be a common cause of polyuria [1]. Here, we describe a rare case of congenital nephrogenic diabetes insipidus (CNDI) observed after pituitary apoplexy. A 24-year-old Chinese woman came to our hospital with complaints of polydipsia and

\footnotetext{
* Correspondence: wanglijun1667@163.com

'Wei Zhang and Yimin Shen contributed equally to this work.

'Department of Endocrinology, Zhejiang Provincial People's Hospital, Affiliated People's Hospital, Hangzhou Medical College, Hangzhou 310003 Zhejiang province, China

${ }^{2}$ Key Laboratory of Endocrine Gland Diseases of Zhejiang Province, Affiliated People's Hospital, Hangzhou Medical College, Hangzhou 310003, Zhejiang province, China

Full list of author information is available at the end of the article
}

polyuria for 6 months. She was diagnosed with pituitary apoplexy 6 months ago, and pituitary surgery was performed. Later, she developed polyuria as well as polydipsia with a plasma osmolality of $301.00 \mathrm{mOsm} /(\mathrm{kg} \cdot \mathrm{H} 2 \mathrm{O})$ and urine gravity of 1.002. However, the water deprivation test demonstrated no significant changes in urine volume and urine gravity in response to fluid depression or AVP administration. The heterozygous mutation in arginine vasopressin receptor type 2 (AVPR2) genes further confirmed her as having CNDI. Therefore, she was given $25 \mathrm{mg}$ hydrochlorothiazide (HCTZ) twice a day, $0.1 \mathrm{mg}$ desmopressin (DDAVP, Minirin) three times a day and $10 \mathrm{mg}$ methimazole twice a day. After

C The Author(s). 2021 Open Access This article is licensed under a Creative Commons Attribution 4.0 International License, which permits use, sharing, adaptation, distribution and reproduction in any medium or format, as long as you give appropriate credit to the original author(s) and the source, provide a link to the Creative Commons licence, and indicate if changes were made. The images or other third party material in this article are included in the article's Creative Commons. licence, unless indicated otherwise in a credit line to the material. If material is not included in the article's Creative Commons licence and your intended use is not permitted by statutory regulation or exceeds the permitted use, you will need to obtain permission directly from the copyright holder. To view a copy of this licence, visit http://creativecommons.org/licenses/by/4.0/. The Creative Commons Public Domain Dedication waiver (http//creativecommons.org/publicdomain/zero/1.0/) applies to the data made available in this article, unless otherwise stated in a credit line to the data. 
that, no polyuria or polydipsia was detected. In addition, differential diagnoses of DI as well as the specific implications of AVPR2 mutations in nephrogenic diabetes insipidus (NDI) are discussed.

\section{Case presentation}

In January 2020, a 24-year-old Chinese woman presented to the Department of Endocrinology with complaints of persistent polydipsia as well as polyuria for nearly 6 months. Six months ago, she was admitted to the neurosurgery department because of headache, and magnetic resonance imaging (MRI) determined pituitary apoplexy, with weakened signal in the posterior pituitary (Fig. 1). Later, she was treated with transnasal transsphenoidal resection for the pituitary mass, and the pathology findings suggested pituitary adenoma (Fig. 2). She was then prescribed with methylprednisolone $40 \mathrm{mg}$ once after pituitary surgery, and her cortisol level (8 am$4 \mathrm{pm}-12 \mathrm{pm}): \quad 143.13 \mu \mathrm{g} / \mathrm{L}-47.12 \mu \mathrm{g} / \mathrm{L}-5.93 \mu \mathrm{g} / \mathrm{L}$, adrenocorticotropic hormone (ACTH) level $(8 \mathrm{am}-4 \mathrm{pm}-12$ $\mathrm{pm}): 33 \mathrm{pg} / \mathrm{mL}-18.8 \mathrm{pg} / \mathrm{mL}-<5 \mathrm{pg} / \mathrm{mL}$, 24-h urine cortisol level was $388 \mu \mathrm{g}$, as well as gonadotrophins and thyroid hormones were all in the normal range at that period. Later, she developed severe polydipsia as well as polyuria, generally urinating every $2 \mathrm{~h}$ with $10 \mathrm{~L}$ per day in total. There was no backache, hand tremors, blurred vision, lower limb puffiness or weight loss. The laboratory examination revealed that the plasma osmolality was $301.00 \mathrm{mOsm} / \mathrm{L}$, urine gravity was 1.002 , potassium was $4.17 \mathrm{mmol} / \mathrm{L}$, and serum sodium was $138.5 \mathrm{mmol} / \mathrm{L}$. Then, she was diagnosed with pituitary surgery-derived central diabetes insipidus (CDI). However, therapeutic strategies with oral desmopressin (gradually increased from $0.2 \mathrm{mg}$ three times a day to $0.3 \mathrm{mg}$ four times a day), pituitrin and potassium chloride were of little efficacy, making the diagnosis undetermined. Later, she was speculated to have NDI and was started with extra HCTZ, along with DDAVP gradually reduced to stop. Surprisingly, her polyuria symptom was alleviated and was then given HCTZ twice a day out of the hospital. However, she stopped the treatment on her own and was admitted for polyuria a second time (Table 1).

The physical examination this time revealed that her blood pressure was $108 / 71 \mathrm{mmHg}$, with a pulse rate of
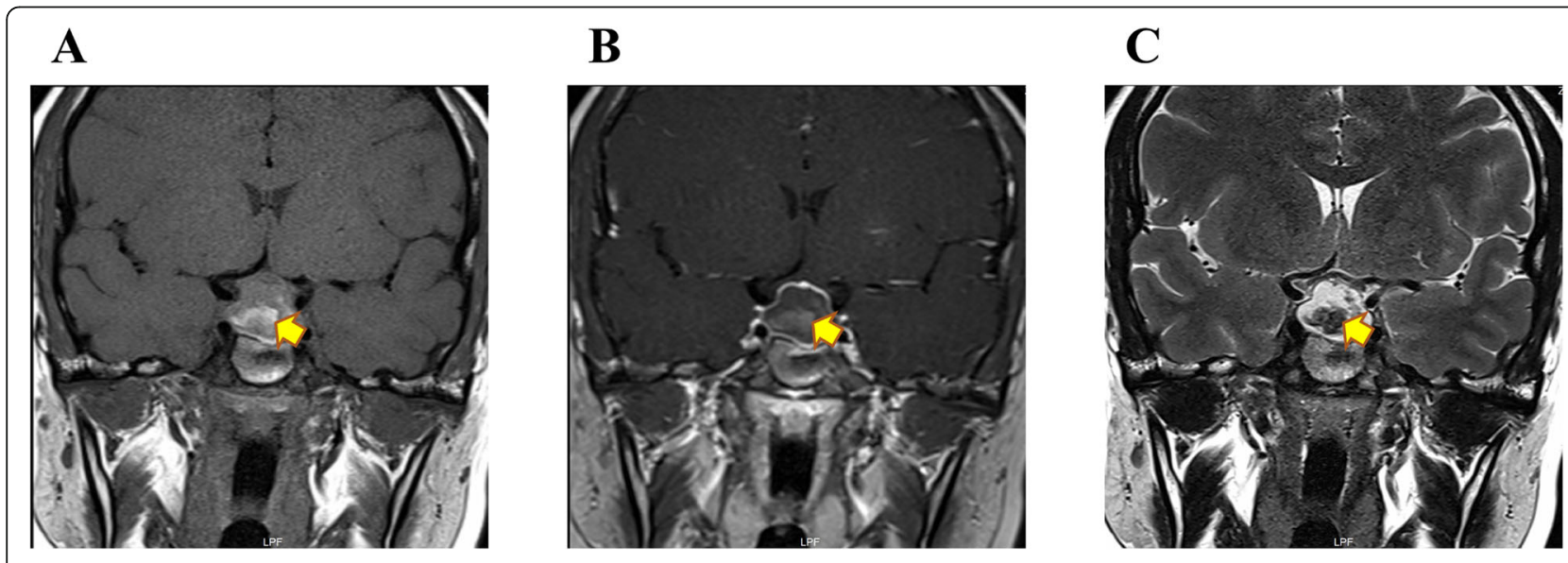

\section{D}

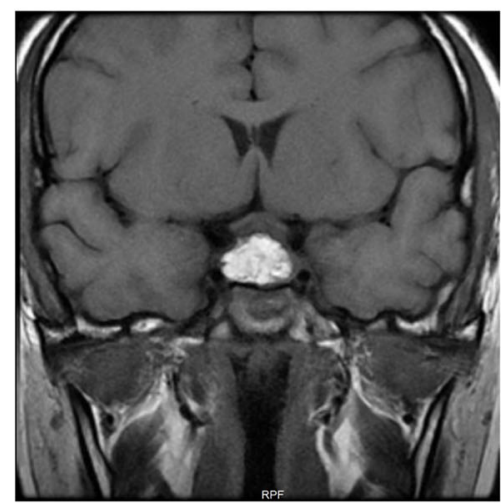

$\mathbf{E}$

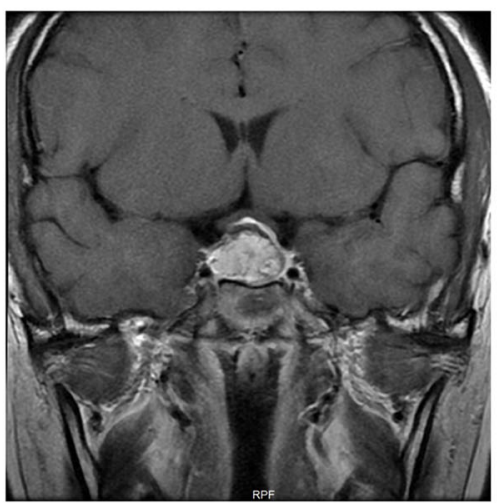

F

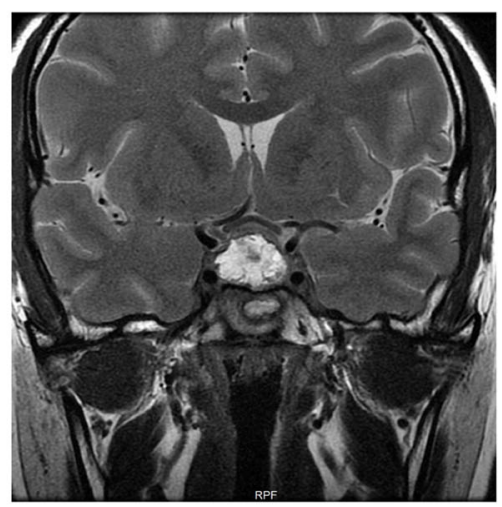

Fig. 1 Coronal magnetic resonance imaging of pituitary in this patient. Before the surgery: pituitary apoplexy, with weakened signal in the posterior pituitary. A. T1; B. T1 + strengthen; C. T2. After the surgery: with stuffing added. D. T1; E. T1 + strengthen; F. T2 


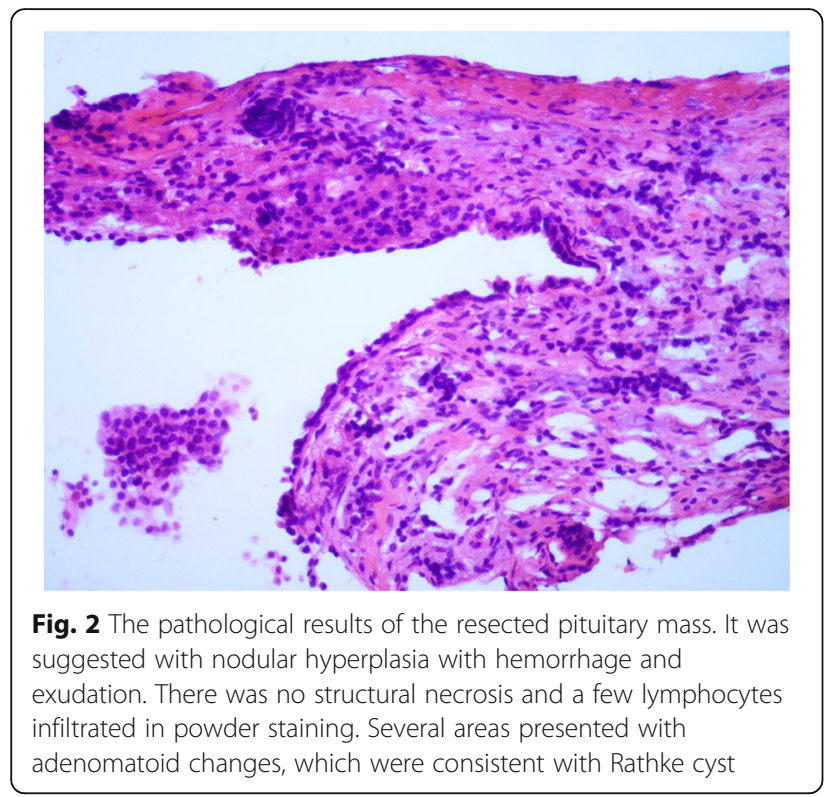

$121 /$ min. Her skin was dry, and the rest of the physical examination was unremarkable. The laboratory examination revealed the following results: urine specific gravity, 1.002; serum sodium, $134.3 \mathrm{mmol} / \mathrm{L}$; plasma osmolality, and $338.00 \mathrm{mOsm} /(\mathrm{kg} \cdot \mathrm{H} 2 \mathrm{O})$. Urinary ultrasonography scans showed normal results. A water deprivation test was performed later with an initial urine gravity of 1.006, plasma osmolality of $281 \mathrm{mOsm} / \mathrm{L}$, and blood pressure of $124 / 72 \mathrm{mmHg}$. Two hours after AVP injection, the plasma osmolality was $299.00 \mathrm{mOsm} /$ (kg.H2O), with urine gravity unchanged (more details are shown in Table 2). In consideration of NDI, she was given a genetic test, and the results suggested a heterozygous mutation in arginine vasopressin receptor type 2
(AVPR2) genes c.914dupC (p.Pro306fs) (Fig. 3). Further investigation revealed that she had slight polydipsia as well as polyuria for over 20 years. She primarily drank 5 $\mathrm{L}$ of water daily along with urine output every $3 \mathrm{~h}$, totaling $4 \mathrm{~L}$ per day; however, she did not attach importance to it at that time. As a result of unfavorable therapeutic efficiency with HCTZ during previous discharge, the history of pituitary surgery as well as the slight remission after DDAVP taken during the water depression test, the diagnosis of CNDI and acquired CDI secondary to pituitary surgery should not be excluded, thereby, DDAVP was primarily utilized for 3 days alone for diagnosis therapy, and the treatment was subsequently changed to 25 mg HCTZ twice a day and $0.1 \mathrm{mg}$ DDAVP three times a day. Currently, no recurrence of polyuria or polydipsia has been detected for more than 6 months, indicating the effectiveness of our therapeutic strategies.

\section{Discussion and conclusions}

The polyuria and polydipsia symptoms of this patient can be mainly attributed to NDI. Although CDI is likely with damage to vasopressin neurons by pituitary apoplexy or surgery, those patients normally develop polyuria 1-4 days after pituitary surgery and resolve spontaneously; less often, DI is permanent. Therefore, temporary treatment with desmopressin in those patients would be valid [2]. Furthermore, the water deprivation test is the standard way to differentiate polyuria-polydipsia-related diseases. Upon thirst, NDI should be taken into account when urinary osmolality remains $<300 \mathrm{mOsm} / \mathrm{kg}$ and does not increase by $>50 \%$ after desmopressin injection. On the other hand, complete CDI should be considered if the urinary osmolality increases above 50\% after desmopressin injection,

Table 1 The flowchart of the urine volume and therapeutic strategies in this patient

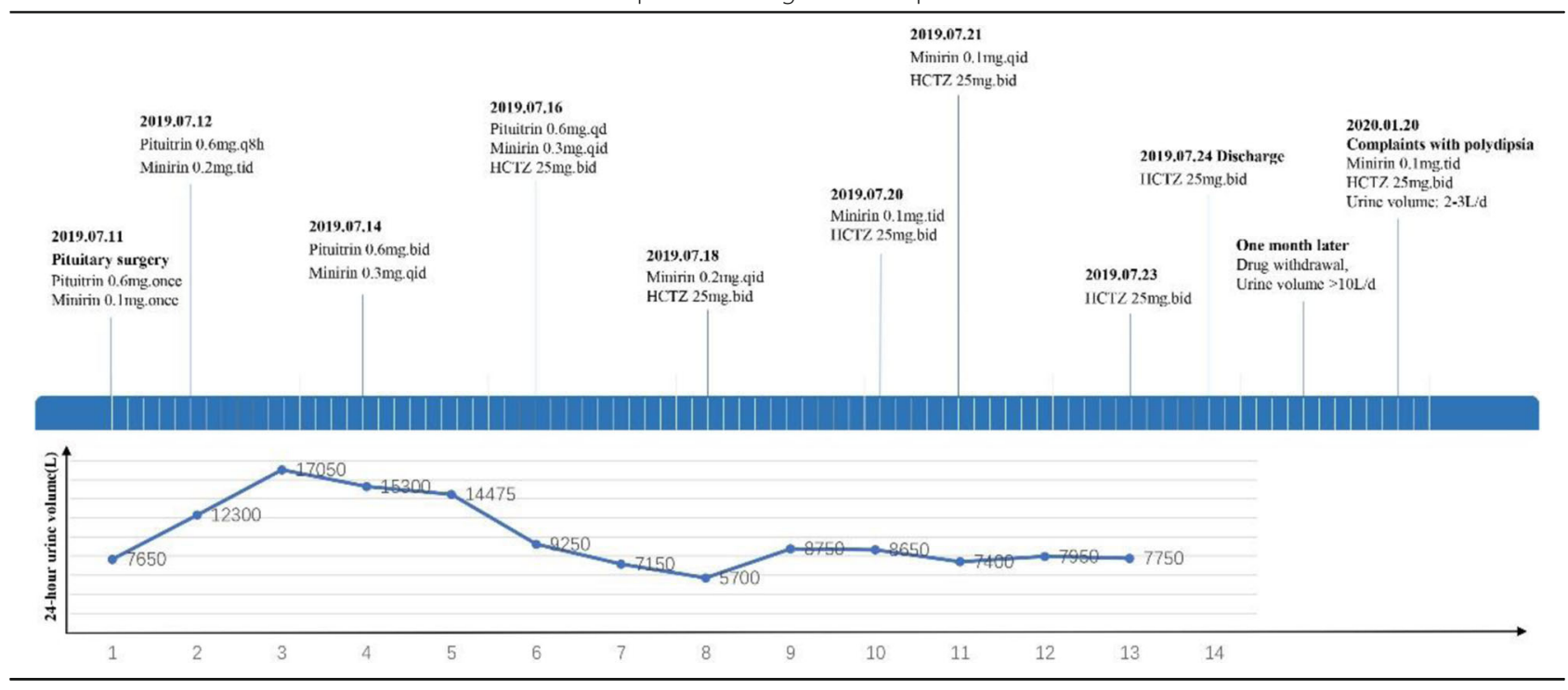


Table 2 Results of the water deprivation test in this patient

\begin{tabular}{llllll}
\hline $\begin{array}{l}\text { Test time } \\
\text { (hour) }\end{array}$ & $\begin{array}{l}\text { Urine volume } \\
(\mathbf{m l})\end{array}$ & Urine gravity & $\begin{array}{l}\text { Weight } \\
(\mathbf{k g})\end{array}$ & $\begin{array}{l}\text { Blood pressure } \\
(\mathbf{m m} / \mathbf{H g})\end{array}$ & $\begin{array}{l}\text { Plasma Osmolality } \\
(\mathbf{m O s m} / \mathbf{L})\end{array}$ \\
\hline 0 & 400 & 1.006 & 62 & $124 / 72$ & $281 \mathrm{mosm} / \mathrm{L}$ \\
$0-0.5$ & 200 & 1.005 & 61.5 & $121 / 72$ & $\mathrm{NA}$ \\
$0.5-1.5$ & 500 & 1.004 & 61 & $121 / 73$ & $\mathrm{NA}$ \\
$1.5-2.5$ & 500 & 1.004 & 61 & $116 / 61$ & $\mathrm{NA}$ \\
$2.5-3$ & 150 & 1.005 & 61 & $106 / 72$ & $293 \mathrm{mosm} / \mathrm{L}$ \\
$3-3.5$ & 100 & 1.005 & 59 & $126 / 73$ & $\mathrm{NA}$ \\
$3.5-4.5$ & 300 & 1.006 & 59 & $112 / 77$ & $299 \mathrm{mosm} / \mathrm{L}$ \\
\hline
\end{tabular}

${ }_{5} \mathrm{U}$ Vasopressin was administrated at $2.5 \mathrm{~h}$

whereas in partial CDI, urinary concentration increases to $300-800 \mathrm{mOsm} / \mathrm{kg}$, with an increase in urinary osmolality> 9\% [3]. Hereby, our patient presented with sustained urinary osmolality of approximately $300 \mathrm{mOsm} /$ $\mathrm{kg}$, which was mainly indicated by the NDI. In addition, the genetic tests of our patient revealed a heterozygous mutation in AVPR2_ex3 c.914dupC (p.Pro306fs), which makes the diagnosis of CNDI reliable. It is noteworthy that her mother as well as her grandmother also suffered from polydipsia and polyuria with a low specific urine gravity, despite two brothers and a sister of her mother as well as her grandfather not admitting to polyuria. In addition, this patient had a brother and two sisters who had no polyuria symptoms (Fig. 4).

DI is a kind of polyuria-polydipsia syndrome that is characterized by the excretion of large amounts of hypotonic urine. After exclusion of osmotic diuresis, such as diabetes mellitus, DI is normally classified into CDI, NDI and psychogenic polydipsia (PPD) [4]. As a result of the changes in soma volume, hypothalamic neuroninduced vasopressin (VP) is the crucial regulator of water permeability in the collecting ducts [5]. CDI is defined as the impaired production or secretion of VP from the central nervous system [6], while NDI is attributed to the failure of the kidneys to concentrate urine in response to AVP [7, 8]. PPD is common in chronic mental illness patients [9], who present with excessive fluid intake without any potential medical cause [10]. The water deprivation test is essential for differentiating polyuria-related disease [11]. In addition, with MRI of the sella, CDI is characterized by the absence of a posterior pituitary bright spot in $\mathrm{T} 1$-weighted imaging, whereas the bright spot is preserved in NDI and PPD; however, an absent bright spot can also be shown in

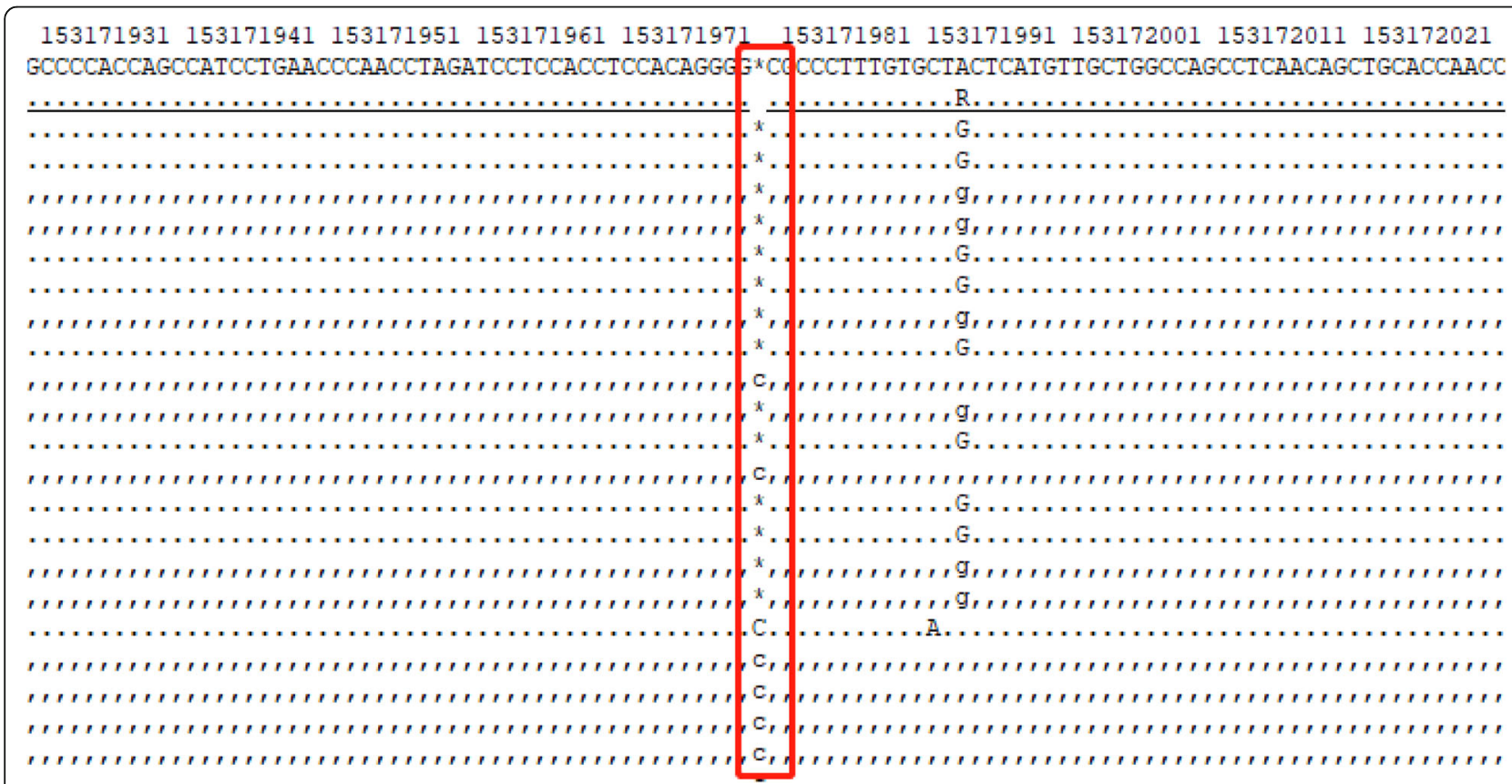

Fig. 3 The gene sequencing result of this patient 


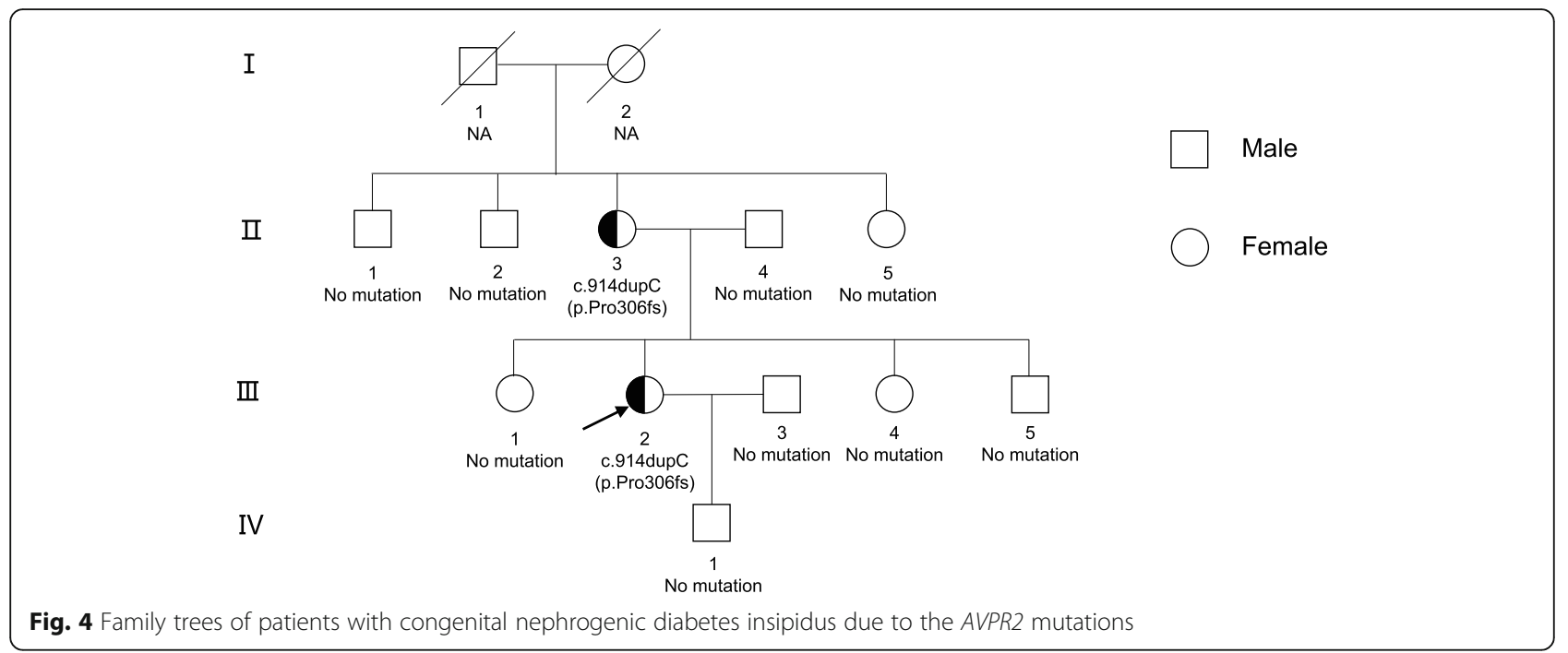

NDI and is possibly attributed to the decreased intracellular AVP stores in the vasopressinergic neurons [12]. Treatment with acquired NDI should target the potential cause, for example, relief of urinary obstruction [13], and the synthetic AVP V2R agonist VP for CDI [14]. Moreover, fluid restriction has become the main strategy in PPD treatment [15].

Recently, more than 250 AVPR2 gene mutations have been identified in the Human Gene Mutation Database [3], among which nearly $55.83 \%$ of mutations in the AVPR2 gene are regarded as missense mutation [16]. AVPR2 mutations usually lead to dysregulated receptors, leading to X-linked NDI and impaired urine concentration ability [16]. Approximately $90 \%$ of familial NDI is caused by X-linked mutations in AVPR2 and thereby affects males [12], whereas heterozygous females show various degrees of preference $[17,18]$. The genetic result of our patient is AVPR2 gene duplication, which leads to a frameshift mutation in the seventh transmembrane domain of exon 3 next to proline 306. Although most NDI patients are found within the first year, some are recognized later due to mild symptoms, especially those with missense mutations [19]. Polyureic states can induce dilation of the urinary tract that leads to impaired bladder function [20]. Thus, the management of dehydration, such as a low-salt diet, thiazide diuretics, and prostaglandin synthesis inhibitors rather than curing the disease, should be emphasized in CNDI [21]. Generally, female patients with AVPR2 mutations tend to exhibit a milder clinical phenotype of partial DI [22]. Here, we may consider polyuria and polydipsia in this patient as pituitary surgery-derived CDI rather than NDI based on the initial clinical manifestation. However, the water depression test as well as the genetic results confirmed it as CNDI. Therefore, direct DNA sequencing of AVPR2 is an accurate approach in helping differentiate the suspected individuals, especially female carriers who present with subtle clinical symptoms.

Although the diagnosis of CNDI accompanied by CDI is conclusive according to her clinical history, the water depression test and genetic results, there still exist several anomalies in this patient. Since she had CDI, the use of Minirin or pituitrin should partially improve polyuria symptoms; nevertheless, there was no significant decrease in urine output after pituitary surgery with large doses of oral vasopressin. Further detailed review of this patient showed that she experienced obvious anxiety during the preoperative period and was given $60 \mathrm{mg}$ of the antianxiety medicine duloxetine as well as $7.5 \mathrm{mg}$ of mirtazapine once a day beginning at the point close to the HCTZ, which also suggested PPD. Unfortunately, as a result of the lack of strict water restriction during that time, the diagnosis of PPD was unreliable. In addition, after elimination of unfavorable emotion as well as withdrawal of the antidepressants, in which there is no spiritual factor interference, the familial NDI along with the CDI should be taken into primary consideration based on the results.

\section{Abbreviations \\ DI: Diabetes insipidus; CNDI: Congenital nephrogenic diabetes insipidus; CDI: Central nephrogenic diabetes; AVPR2: Arginine vasopressin receptor type 2; HCTZ: Hydrochlorothiazide; NDI: Nephrogenic diabetes insipidus; DDAVP: Desmopressin; MRI: Magnetic resonance imaging; \\ ACTH: Adrenocorticotropic hormone; PPD: Psychogenic polydipsia}

\section{Acknowledgements}

Thanks for the support of the Zhejiang Provincial People's Hospital, Department of Endocrinology and the assistance of patient who participated in our study.

\section{Authors' contributions}

WZ attended the patient. WZ and YMS wrote the manuscript. LW, YZR and YBX reviewed the literature. All authors read and approved the final manuscript. 
Funding

No.

\section{Availability of data and materials \\ Not applicable.}

\section{Declarations}

Ethics approval and consent to participate

Not applicable.

\section{Consent for publication}

All individuals gave written consent for their clinical details along with identifying images to be published in this study.

\section{Competing interests}

The authors declare that they have no competing interests.

\section{Author details}

'Department of Endocrinology, Zhejiang Provincial People's Hospital, Affiliated People's Hospital, Hangzhou Medical College, Hangzhou 310003, Zhejiang province, China. ${ }^{2}$ Key Laboratory of Endocrine Gland Diseases of Zhejiang Province, Affiliated People's Hospital, Hangzhou Medical College, Hangzhou 310003, Zhejiang province, China. ${ }^{3}$ Department of Cardiology, The Second Affiliated Hospital of Zhejiang University School of Medicine, Hangzhou 310009, Zhejiang province, China. ${ }^{4}$ Department of Endocrinology, The Second Affiliated Hospital of Zhejiang University School of Medicine, Hangzhou 310009, Zhejiang province, China.

Received: 27 December 2020 Accepted: 13 April 2021

Published online: 21 April 2021

\section{References}

1. Robertson GL. Diabetes insipidus: differential diagnosis and management. Best Pract Res Clin Endocrinol Metab. 2016;30(2):205-18. https://doi.org/10.1 016/j.beem.2016.02.007.

2. Verbalis JG. Acquired forms of central diabetes insipidus: mechanisms of disease. Best Pract Res Clin Endocrinol Metab. 2020;101449.

3. Christ-Crain M, Bichet DG, Fenske WK, Goldman MB, Rittig S, Verbalis JG, et al. Diabetes insipidus. Nat Rev Dis Primers. 2019;5(1):54. https://doi.org/1 0.1038/s41572-019-0103-2.

4. Hui C, Radbel JM. Diabetes Insipidus. Treasure Island (FL): StatPearls; 2017.

5. Bockenhauer D, Bichet DG. Pathophysiology, diagnosis and management of nephrogenic diabetes insipidus. Nat Rev Nephrol. 2015;11(10):576-88. https://doi.org/10.1038/nrneph.2015.89.

6. Sands JM, Klein JD. Physiological insights into novel therapies for nephrogenic diabetes insipidus. Am J Physiol Ren Physiol. 2016;311(6): F1149-F52. https://doi.org/10.1152/ajprenal.00418.2016.

7. Morin D. Vasopressin V2 receptor-related pathologies: congenital nephrogenic diabetes insipidus and nephrogenic syndrome of inappropiate antidiuresis. Nephrol Ther. 2014;10(7):538-46. https://doi.org/10.1016/j. nephro.2014.09.002.

8. Namatame-Ohta N, Morikawa S, Nakamura A, Matsuo K, Nakajima M, Tomizawa $K$, et al. Four Japanese patients with congenital Nephrogenic diabetes Insipidus due to the AVPR2 mutations. Case Rep Pediatr. 2018; 2018:6561952

9. Penders TM, Stanciu CN, Ganpat P, Ingersoll JA. Psychogenic polydipsia, hyponatremia and osmotic myelinolysis. BMJ Case Rep. 2015;2015(jan27 2): bcr2014207508. https://doi.org/10.1136/bcr-2014-207508.

10. Unger M, Xiong $\mathrm{G}$. Treatment of refractory psychogenic polydipsia with lithium. Ann Clin Psychiatry. 2017;29(2):146-7.

11. Timper K, Fenske W, Kuhn F, Frech N, Arici B, Rutishauser J, et al. Diagnostic accuracy of Copeptin in the differential diagnosis of the polyuria-polydipsia syndrome: a prospective multicenter study. J Clin Endocrinol Metab. 2015; 100(6):2268-74. https://doi.org/10.1210/jc.2014-4507.

12. Schernthaner-Reiter MH, Stratakis CA, Luger A. Genetics of diabetes Insipidus. Endocrinol Metab Clin N Am. 2017;46(2):305-34. https://doi.org/1 0.1016/.ecl.2017.01.002

13. Carpenter CP, Rawson A, Hains DS, Giel DW. Resolution of diabetes Insipidus after Pyeloplasty: a case report and review of the literature. Urology. 2018; 115:168-70. https://doi.org/10.1016/j.urology.2018.02.017.
14. Lu HA. Diabetes Insipidus. Adv Exp Med Biol. 2017;969:213-25. https://doi. org/10.1007/978-94-024-1057-0_14.

15. Ahmed SE, Khan AH. Acetazolamide: treatment of psychogenic polydipsia. Cureus. 2017:9(8):e1553. https://doi.org/10.7759/cureus.1553.

16. Spanakis E, Milord E, Gragnoli C. AVPR2 variants and mutations in nephrogenic diabetes insipidus: review and missense mutation significance. J Cell Physiol. 2008;217(3):605-17. https://doi.org/10.1002/jcp.21552.

17. Fujimoto M, Imai K, Hirata K, Kashiwagi R, Morinishi Y, Kitazawa K, et al. Immunological profile in a family with nephrogenic diabetes insipidus with a novel $11 \mathrm{~kb}$ deletion in AVPR2 and ARHGAP4 genes. BMC Med Genet. 2008;9(1):42. https://doi.org/10.1186/1471-2350-9-42.

18. Bai Y, Chen Y, Kong X. Contiguous 22.1-kb deletion embracing AVPR2 and ARHGAP4 genes at novel breakpoints leads to nephrogenic diabetes insipidus in a Chinese pedigree. BMC Nephrol. 2018;19(1):26.

19. Fujimoto M, Okada S, Kawashima Y, Nishimura R, Miyahara N, Kawaba Y, et al. Clinical overview of nephrogenic diabetes insipidus based on a nationwide survey in Japan. Yonago Acta Med. 2014;57(2):85-91.

20. Fujiwara TM, Morgan K, Bichet DG. Molecular biology of diabetes insipidus. Annu Rev Med. 1995;46(1):331-43. https://doi.org/10.1146/annurev.med.4 6.1.331.

21. Bichet DG. Genetics in endocrinology pathophysiology, diagnosis and treatment of familial nephrogenic diabetes insipidus. Eur J Endocrinol. 2020 183(2):R29-40. https://doi.org/10.1530/EJE-20-0114.

22. Demura M, Takeda Y, Yoneda T, Oda N, Bando Y, Mabuchi H. Surgical stressinduced transient nephrogenic diabetes insipidus (NDI) associated with decreased Vasopressin receptor2 (AVPR2) expression linked to nonsensemediated mRNA decay and incomplete skewed X-inactivation in a female patient with a heterozygous AVPR2 mutation (c. 89-90 delAC). Clin Endocrinol. 2004;60(6):773-5.

\section{Publisher's Note}

Springer Nature remains neutral with regard to jurisdictional claims in published maps and institutional affiliations.
Ready to submit your research? Choose BMC and benefit from:

- fast, convenient online submission

- thorough peer review by experienced researchers in your field

- rapid publication on acceptance

- support for research data, including large and complex data types

- gold Open Access which fosters wider collaboration and increased citations

- maximum visibility for your research: over $100 \mathrm{M}$ website views per year

At $\mathrm{BMC}$, research is always in progress.

Learn more biomedcentral.com/submissions 